\title{
Back to the original: incidences of web citations in South African electronic legal journals for the period 2005 to 2012
}

\author{
Solomon Bopape ${ }^{1}$ \\ solomon.bopape@ul.ac.za
}

\begin{abstract}
Received: 30 September 2013
Accepted
\end{abstract}

\begin{abstract}
The primary and secondary sources of information in law are today available and accessible through the World Wide Web and online databases to the advantage of lawyers, legal scholars, writers, researchers and academics, as well as to the public at large. With the increased usage of the internet for legal research and writing, citation and referencing of online legal information sources also become issues of concern to the legal scholarship community. In order to test the extent to which online legal information sources are used by legal researchers and academics, an analysis of the incidences of web citations in the South African electronic legal journals between 2005 and 2012 was conducted. Despite an ever-increasing availability of primary and secondary legal information sources on the internet, the citation counting of domain names found in Uniform Resource Locators (URLs) searched from the SA e-publications law collection database revealed both an increased and decreased usage of online legal information sources in the South African legal journals. Explanations for the increased and later decreasing use of web citations in the South African law journals during the specified period should, therefore, be an issue for concern for those who are involved with research on citation patterns of the web or internet resources.
\end{abstract}

Keywords: Web citations, internet citations, citation counting, legal research, legal periodicals, law journals, legal scholarly communication, South Africa

\section{Introduction}

Widdison (1997:1) stated that research in the legal field has, over the past years, centred on the paper-based law library. Legal information sources were available in print format and were obtained manually, for instance, by physically locating legislation, law reports, legal articles or any legal information sources that contain the needed information from the law library. Electronic versions of primary and secondary sources of information in law today are widely available and accessible to the public through the Internet (Du Plessis 2008: 32). Many court decisions, legislation, regulations, commentaries, law journal articles and case notes can be accessed freely through websites that endorse free and open access to legal scholarship information, while some can only be accessed through subscription to the fee-based online databases. Whiteman (2010: 32) noted that even a simple Google search allows access to legal documents that were not necessarily easily available or accessible when searching printed information resources. Accessing legal information freely and instantly from the internet in an electronic format across jurisdictional lines has been a development welcomed by legal researchers, scholars, academics and lawyers (Howland \& Wang 2011: 165).

Barratt and Snyman (2002:16) highlighted that there is a substantial amount of free legal information on the internet, specifically on South African law. Examples of free legal information in South Africa available on the internet include judgments of the Constitutional Court, Land Claims Court, Supreme Court of Appeal and other courts, all of which can be accessed from the Southern African Legal Information Institute (SAFLII). Just like in other countries that have legal information institutes, the South African legal academics and researchers have free access to the current case law through the court-operated databases on the SAFLII website. Recently, electronic copies of journals have been added to the SAFLII website, including the Potchefstroom electronic law review, De rebus, De jure, SADC law journal, as well as Law, democracy and development.

A larger amount of free legal information on the internet is also provided by government departments (Badertscher \& Melnick 2010:13). The new government of South Africa adopted a principle that every citizen should have free access to government legal information because free access to such information is the same as access to justice and also enhances transparency in government, as well as ensuring improved prospects of the rule of law (Germain 1999: 291). The South African legislation, policy documents, Bills of Parliament and other public documents are, as a result, also being made available and accessible to the public through the government departmental websites.

The South African Bibliographic Network (SABINET Online) also makes primary sources such as Acts, Bills and other government documents accessible through subscription to Government gazette online and SABINET legal products databases. Statutes and judgments can also be accessed through subscription to either Juta or LexisNexis (South Africa) electronic databases. Bekker (1997: 70) referred to Juta and Butterworths (now LexisNexis) electronic information products as the most convenient research tools available to South African lawyers with regard to both statutory sources

1. Dr Solomon Bopape is a Senior Lecturer for the Programme of Information Studies in the School of Languages and Communication Studies: Department of Media, Communication and Information Studies at the University of Limpopo. 
and reported cases. Practically, most lawyers are interested in the South African law reports, South African criminal law reports, South African statutes, Jutalex provincial legislation, South African tax library, Labour law library and Constitutional law library, all administered by Juta. Products that are currently available from LexisNexis (South Africa) include South African statutes, Constitutional law library, Labour law library, VAT library, Tax library and All South African law reports that are also being used by the legal professionals. LexisNexis and Juta also host unreported cases, namely, Judgements online (JOL) and Juta daily reports (JDR) respectively.

Legal researchers can also access recent South African online and full text published articles available through subscription to SA e-publications (2001 onwards), also published by SABINET, which provides the user with full text journal articles from a range of South African published journals in law and other subjects. From 1 November 2011 , SABINET launched a new database specifically for law journal articles called the SA e-publications law journal collection. The advantage of this product is that it contains those journals that are only relevant to law. But it appears that this resource has been cancelled, if not suspended, by SABINET whilst the current interface was being introduced. However, the database was still running on the old SABINET SA e-publications interface during the time when this study was undertaken. Other journals such as De rebus, which is the South African attorney's journal, as well as other electronic journals, like Employment law, De jure, Tydskrif vir hedendaagse Romeins-Hollandse reg (THRHR), are also available from the LexisNexis legal products, whereas Juta also hosts journals such as the Industrial law journal. However, the De jure and De rebus journals have also been recently added on the SABINET online electronic law journals. All these legal information products mentioned above are South African electronic tools that can assist legal researchers in finding legal information and producing more information about the legal profession. The ability to conduct fast and efficient legal research utilising the above-mentioned products and being able to cite them accurately and precisely are regarded as the cornerstone for any legal research (Du Plessis 2004: 86).

As legal information becomes more prevalent and available on the internet in South Africa, the legal academics and researchers who utilise these sources of information are required to provide authoritative data to support arguments that they present in their review articles, publications or works. Ching (2007: 388) commented that the more legal research is conducted online, the more it is reasonable to conclude that there will be a corresponding increase in citations to the internet resources in the legal publications produced. Noticeably, the internet domains that appear more frequently in the articles published in the South Africa law journals will have a role in scholarly communication in that field. According to Yang et al. (2012), web citations have also been proposed as data sources for studying academic citations. They further noted that numerous studies that have been devoted to studying web citations, with specific emphasis on their incidences. Vaughan and Thelwall (2003) noted that the web citations as an information source are becoming an object of research. Knowing whether or not legal researchers rely on online information resources in their scholarly communication is valuable because such reliance will assist the academic and law libraries in their collection development decisions, that is, in as far as selection of digital or electronic resources are concerned.

With the dominance of online legal information sources and the increased awareness of the availability of such information by legal academics, researchers and writers in South Africa, it is essential to assess the usage of these information sources in legal scholarly communication. This study was, therefore, carried out in order to determine the extent or rate at which legal information sources obtained from the internet are used by legal researchers in producing legal reviews, comments, notes and articles in the South African legal journals. Citation counting of domain names found in the footnotes, endnotes, bibliographies, text and lists of references was carried out to determine the extent to which internet resources occur in those law journals that were published in electronic and full text format. This study attempts to explore the contribution of the internet to scholarly communication in the legal field by counting the incidences or occurrences of web citations in the research articles published in South African legal journals or periodicals between 2005 and 2012. This study also seeks to examine the academic behaviour of legal academics, scholars, researchers and writers with regard to the utilisation of information sources obtained from the internet. For the purpose of this study, "legal researcher" is any legal professional, legal writer, legal academic and even a lawyer who contributes to scholarly communication in the legal field by publishing articles in accredited law journals.

\section{Literature review}

Each assertion or fact of law made in any legal publication will require a footnote or citation (Delgado 1986: 451). This entails that, for whatever reason a legal researcher writes a review article or a publication, there is nearly always a primary precedent in the form of either legislation or a case, or a secondary source in a form of a review article or a book, from which the legal researcher has referred. Aldrich (2008: 203) remarked that attorneys, scholars, law students and the public turn to primary sources when seeking a rule of law or precedent for a particular legal issue. There are, therefore, only a few legal reviews or works that can be published without referring from the original or other information source or sources. Developments in law, legal research and writing, therefore, rely heavily on citations and footnotes. The use of citations to locate references to cases, statutes and other legal materials is regarded as an essential part of the practice of law and legal research (Vreeland 2000: 12). Citations are the cornerstone upon which judicial opinions and law reviews stand (Liebler \& Liebert 2013: 273).

Adriaanse and Rensleigh (2011: 170) noted that studying citation patterns or citation analysis involves counting the number of times a paper or a researcher is cited. Therefore, one way of measuring the extent to which published information is used, is to count the number of times a preceding work is cited in subsequent works. Citation counts are commonly used to measure the quality of research outputs and, as such, they are used to evaluate the performance of individual researchers, organisations, and associations. In the legal field, citation counts have been used to assess the 
influence and visibility of legal publications and judicial prestige of court judges (Vreeland 2000: 12). For example, Smyth (2001) used citation analysis to determine the judicial prestige of the Federal Court judges through counting the number of times the judgements that they had authored have been cited in later cases. The more frequently the decisions authored by a particular court judge are cited, the more the judicial prestige of that particular judge grows. In the academic world, citation counts are used to rate the academic prestige of researchers and academics. The quality of works published by a particular academic or researcher is reflected in the number of occasions that his or her works are cited in subsequent works and publications in which they publish their articles. Libraries use citation counting to make collection development decisions because librarians want to acquire relevant materials that are frequently used by library patrons (Obuh \& Babatope 2011).

With the prevalence of electronic information resources on the internet, it is also necessary for researchers to focus attention on the frequency with which the authors use web information to document their scholarly research (Casserly \& Bird 2003: 300). Such studies will assist in determining the impact that information obtained from the internet has on scholarly communication and thereby assist librarians who are making collection development decisions pertaining to electronic resources. Mardani (2012:19) remarks that citations to the web resources have been studied since as early as the mid-1990s. Ngulube and Thompson (2008:160) also mentioned a number of citation analysis studies that attempted to establish the effects of the web on citation patterns, with measures based on citation counts. Several studies that have been conducted with regards to web citations in the legal field concentrated much on whether or not the documents cited from the web were still available after a particular period (Oermann et al. 2008: 347). This is done by checking if the web addresses cited would still lead to the documents that were linked to those addresses. Many of these studies have discovered that the web citations or the links either change or disappear (Mardani 2012:19). According to Davis (2006: 639), the most in-depth look at web citations in law reviews was done by Rumsey (2002), who focused mainly on the permanence of cited legal information on the internet, that is, whether a particular web address contained the same information when tested as it did when cited. The study by Rumsey (2002) found an availability rate that declined from 61.80 to 30.27 percent per article and a lack of parallel citations to paper sources.

Some studies in the legal field concentrated on the incidences of web citations in legal court opinions, judgements and decisions. Wilkerson (2006) tracked the use and growth of internet citations between 1996 and 2006 in the United States (U.S.) Supreme Court opinions. Ching (2007) conducted a similar survey on the use of internet citations in the opinions of the Washington Supreme Court and Washington appellate courts from 1999 to 2005. In these studies, it was found that the overall number of internet citations found in the U.S. Supreme Court opinions and the Washington Supreme and appellate courts was surprisingly low, despite the ever-increasing amounts of legal information on the web.

The difference between the above-mentioned studies and the current study is that the former concentrated more on the prevalence of internet citations of the court opinions and judgements, whilst the current study measured the usage of internet citations appearing in the articles published in the online legal journals in South Africa. The current study did not attempt to establish the permanence of URLs or domain names as previous studies in the U.S. did, but rather to reveal how frequently legal researchers in South Africa used internet resources in the journal articles that they published during a specified period. The current study might be similar to the one conducted by Canick (2002), wherein a group of law articles was examined to determine the proportion of cited web resources that are findable online by using databases such as LexisNexis and Westlaw.

\section{Method and materials}

The main purpose of this study was to measure the rate at which frequencies of internet domain names occurred in the South African electronic legal periodicals between 2005 and 2012. Only electronic legal periodicals that are indexed in the SA e-publications law collection database were included in the study. The list of electronic law journals on the SA epublication is available on the SABINET online website. In that list there were forty-four journal titles which, according to SABINET Implementation and Support consultation office, contained 10,315 articles.

Electronic information has specific locators and addresses (Rozenberg 1997). Expectations regarding the types of web resources to be cited were, therefore, derived from the assumption that almost all the URLs would have the domain names representing the internet information resource. URL stands for Uniform Resource Locators which are defined as standard formats for identifying locations on the internet. A domain name is the unique name that identifies an internet site and it is found after the final "dot" of a URL, such as in the following:

- .gov for government;

- .org for non-profit organisation;

- .edu for education institution;

- .com for commercial organisation; and

- . .net for networking organisation (Wallace 2012: 33).

There are a number of domain names registered and used on the internet. Only the above-mentioned domain names were used because they are some of the first popularly known domain names and they are generally referred to as generic and international top-level domain names (Aguillo 2012: 345; Wallace 2012: 33). The other two domain names or identifiers representing unreported law reports, namely, Judgements online (.jol) hosted by LexisNexis and Juta daily reports (.jdr) previously hosted by SABINET, were also used in this study to test how the legal researchers used 
unreported decisions in their published legal articles indexed in the specified database. These were included in the study because unreported cases are some of the primary authority that can be obtained electronically. Unreported decisions are judicial opinions that have not been published in any official or near-official case reporter. They are also called "unpublished decisions", "unreported opinions" and "unpublished opinions" (Zimmerman 2013). The internet citations in this study were, accordingly, identified by checking if any of the above-mentioned domain names or identifiers appeared in the footnotes, title, summary, full text or anywhere in the articles indexed by running or conducting a search on the internet through the specified database using these domain names as search terms. The search was conducted in January 2012 in such a way that the domain name was searched for anywhere in the article because there is no provision to search by footnotes or references in the specified database. It was noted that some domain names may refer to something else; each domain name was therefore preceded by a full stop or "dot", to ensure that they do not mean something different. The number of "hits" each domain name had for each year was recorded on a table and then transported into an Excel spreadsheet so that they could be analysed.

\section{Results}

\subsection{Web citations}

The total number of domain names found from the SA e-publications law journal collection database from 2005 to 2012 is 3,497 . This constitutes $34 \%$ of the 10,315 articles indexed in the SA e-publication law collection database. Table 1 below represents the pattern of use of domain names in South African law journal articles over a period of eight years.

Table 1 Number of web citations $(\mathrm{N}=3,497)$

\begin{tabular}{lccccccccc}
\hline & $\mathbf{2 0 0 5}$ & $\mathbf{2 0 0 6}$ & $\mathbf{2 0 0 7}$ & $\mathbf{2 0 0 8}$ & $\mathbf{2 0 0 9}$ & $\mathbf{2 0 1 0}$ & $\mathbf{2 0 1 1}$ & $\mathbf{2 0 1 2}$ & Total (\%) \\
\hline .com & 79 & 139 & 259 & 366 & 253 & 247 & 217 & 63 & $1,623(46 \%)$ \\
.edu & 3 & 5 & 22 & 22 & 9 & 12 & 13 & 4 & $90(3 \%)$ \\
.gov & 23 & 24 & 45 & 63 & 51 & 50 & 30 & 14 & $300(9 \%)$ \\
.net & 125 & 115 & 144 & 144 & 131 & 103 & 93 & 50 & $905(26 \%)$ \\
.org & 16 & 19 & 31 & 40 & 43 & 23 & 19 & 18 & $209(6 \%)$ \\
.jdr & 14 & 19 & 20 & 20 & 17 & 10 & 9 & 5 & $114(6 \%)$ \\
.jol & 17 & 27 & 28 & 41 & 55 & 28 & 45 & 15 & $256(7 \%)$ \\
Total & $277(8 \%)$ & $348(10 \%)$ & $549(16 \%)$ & $696(20 \%)$ & $559(16 \%)$ & $473(13 \%)$ & $426(12 \%)$ & $169(5 \%)$ & $3,497(100 \%)$ \\
\hline
\end{tabular}

The largest number of incidences occurred in 2008 with $696(20 \%)$ hits, followed by 559 and $549(16 \%)$ hits that occurred in 2009 and 2007 respectively. The year 2010 reflected the fourth-highest incidences of internet citations, namely 473 (13\%), followed by 2011 and 2006 with $426(12 \%)$ and $348(10 \%)$ respectively. In 2005, there were $277(8 \%)$ web citation incidences appearing in the database, followed by $169(5 \%)$ hits found in 2012, the lowest number of hits for any of the years studied.

The number of internet citations was low in 2005 relative to other years and grew steadily in 2006 and 2007 to a point where the numbers doubled in 2008. After that, the web citation incidences started decreasing, that is, from 2009 to 2012. By 2012, there were only 169 domain names appearing in the review articles. This means that the number of internet citations grew by $14 \%$ from 2005 to 2008 , and after that declined by $13 \%$ from 2008 to 2012 . Figure 1 below depicts how domain names or web citation incidences found in South African legal periodicals increased from 2005 to 2008, and decreased from 2009 to 2012. 
Figure 1 Development of web citations from $2005-2012(\mathrm{~N}=3,497)$

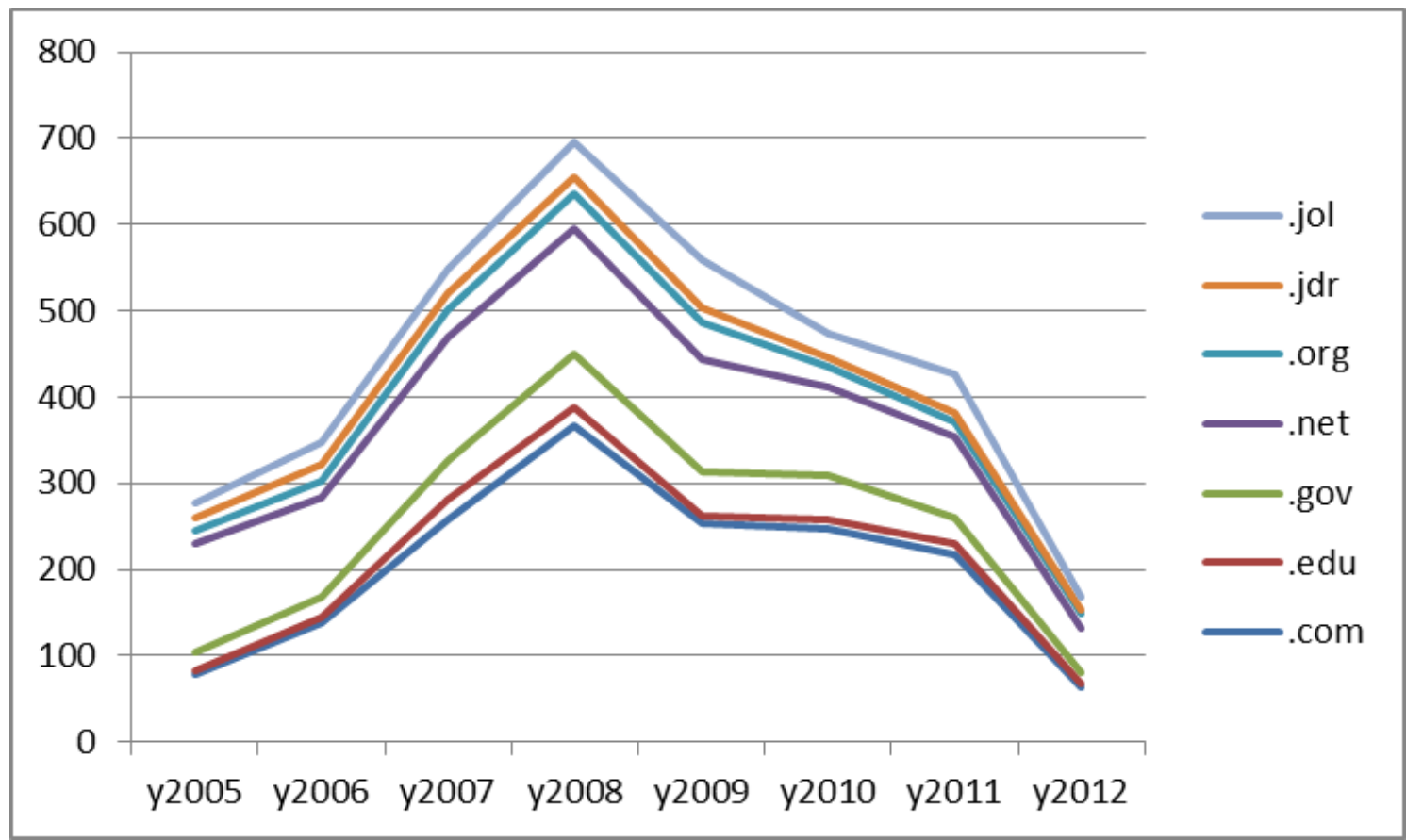

\subsection{Domain names}

The domain name that appears most frequently in the articles is ".com", for commercial organisations, with 1,623 (46\%) incidences, followed by ".net" for networking organisations with $905(26 \%)$ incidences. The ".gov" and the ".jol" domain names are the third and fourth, with $300(9 \%)$ and $256(7 \%)$ incidences, respectively, followed by the ".org" domain name with $209(6 \%)$ incidences. The domain names with the lowest number of incidences were ".jdr" and ".edu" with 114 and 90 incidences respectively, each constituting three (3\%) occurrences. Figure 2 below depicts the frequency of occurrences of domain names in the articles published in South African legal periodicals in a form of a pie chart.

Figure 2 Domain name incidences $(\mathrm{N}=3,497)$

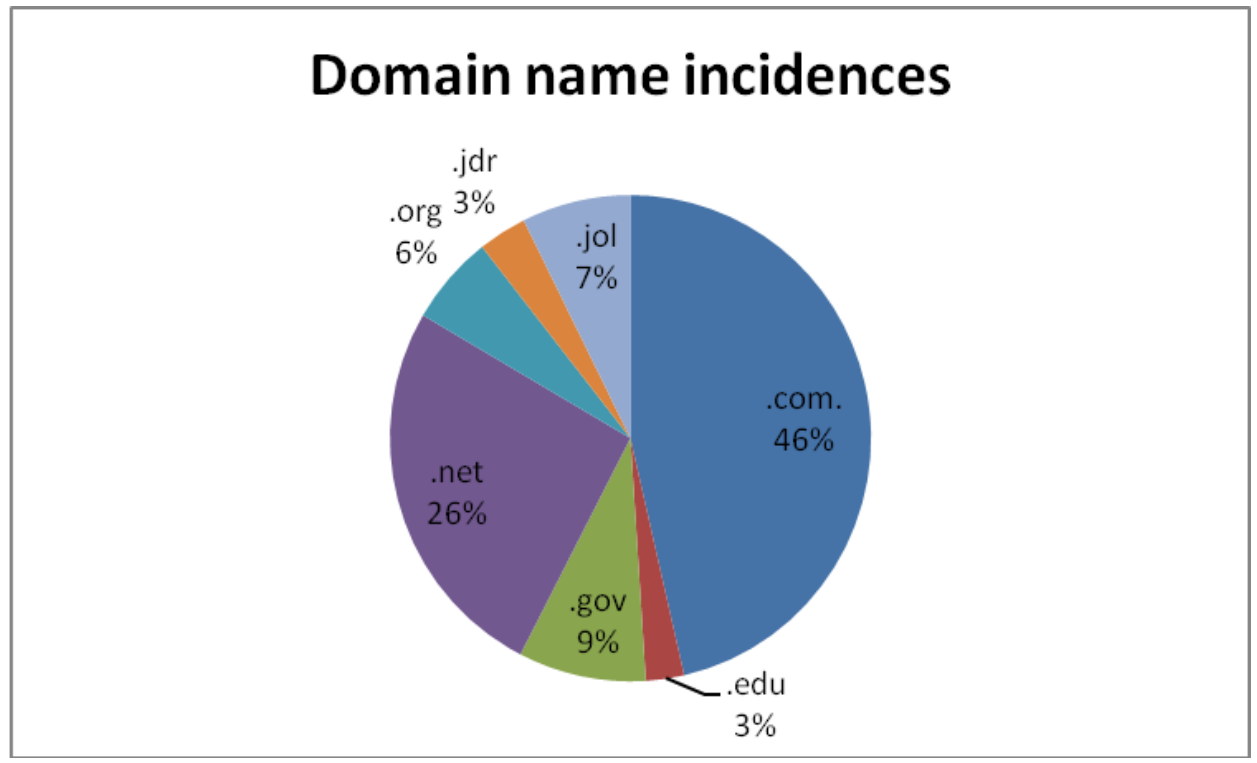

\section{Discussion of results}

The results of this study depict an increased usage of the web from 2005 to 2008, as well as a decrease in usage of internet sources among legal researchers from 2009 to 2012. This may be attributed to a number of factors. Ching (2007: 400) points out that, while there is an increasing amount of legal information available on the internet, not all legal sources are yet available online, particularly valuable secondary sources and other old legal materials. There is, therefore, a 
possibility that legal researchers might be using materials that are not yet available in electronic format, but only available in printed format. In South Africa, for example, earlier issues of the Government gazette that contain much of the primary legislation from 1910 to 1993 became electronically available just in 2010 through subscription to the retrospective Government gazette online administered by SABINET. It is only recently that, with the coming into prominence of digitisation, most of the old legal materials, like the Government gazette are now becoming available electronically.

Furthermore, the legal researcher who uses the electronic Government gazette, for example, does not have to cite the internet resource from which the source was obtained, because the electronic version found online looks exactly the same as the printed source. The same applies to law reports obtained from databases such as Westlaw, Justis online, Heinoline, Jutastat and the like. It is therefore difficult to tell if the case or the legislation was obtained from the internet or from a printed resource (Rumsey, 2007-8: 210). There is also a possibility that some legal researchers might be attached to libraries that have no access to fee-based electronic databases such as the one mentioned above.

Wu (2005: 237) also cautioned that online materials are not always accurate and authenticated. From both academic and legal perspectives, this unreliability might have fostered distrust towards e-documents by legal scholars and researchers, thus leading to dependence on print publications. Apparently, this might be the reason behind the decrease in usage of online resources from 2009 to 2012. This view is supported by Manz (2001: 1296) who pointed out that one factor discouraging the use of some internet documents is lack of confidence in their reliability and accuracy. Wilkerson (2006: 333) also warned that some internet citations may lack permanence, sometimes referred to as "link rot" or "link decay". Legal researchers who might have experienced frustrations due to "link rot" may not use internet resources again because electronic resources are not necessarily as stable as traditional printed references (Wilkerson 2006: 333). Aldrich (2008: 204) also reveals the problems that people often encounter when trying to use the internet: for instance, where the link to a website no longer exists, being redirected to another source, or the website having been updated since the last time it was visited. However, perhaps with the introduction of the Digital Object Identifiers (DOls) by some vendors and publishers, the problem of lack of permanence of internet resources may be resolved.

Some government publications obtained from the internet may also pose a problem in as far as their authenticity is concerned. The Authentication Survey, completed by the Association of American Law Libraries (AALL) members in 2006, found that a significant number of the state online legal resources in the U.S. are official but none are authenticated or afford ready authentication by standard methods (Mathews \& Baish 2007; and Dixon 2007: 43). In South Africa, for instance, some legislation that appear on government departmental websites, especially those that are in HTML format, are necessarily not the original versions that appear in the official printed Government gazettes, which is the original authoritative source of legislation in South Africa. When one is required to cite such legislation, it may become very difficult because some of the documents do not show the actual act number as well as the official Government gazette number and other bibliographic details from which the legislation originates. Researchers are, therefore, sometimes forced to go back to the original and official documents that are in printed format for citation and referencing purposes.

The other problem associated with increased and later decreased usage of online legal information resources might relate to lack of standards for citing online sources in law, and the fact that the manner of citing online sources is constantly changing and developing as these online products evolve. It appears there is an ad hoc approach towards the citation of electronic materials for legal research, where individual academics and researchers have used their own methods based on their preferences (Bohill 1997: 212). Likewise, institutions and publishers have their own style preferences, for example, Liebler and Liebert (2013: 295) argue that Westlaw and LexisNexis use different methods of handling internet citation formatting. Therefore, some legal researchers might argue that the advent of internet information is making legal citation a difficult and daunting task. According to Sherman (2013:17), legal scholars suggest that the shift from print-based to online research has affected the nature of legal authority. Fletcher and Greenhill (1995: 211) have long suggested that an adequate and consistent method for citing and referencing materials from the internet needs to be developed because the academic status of researchers who publish through the internet will be affected. Before then, Bohill (1997: 211) had already stated that legal researchers and professionals require a universal citation format that is simple and consistent.

Germain (1999: 294) argued that student-edited law reviews prevalent in law schools are still under obligation to cite the printed source when they do cite-checking or bibliographic verification of sources. This means that, in some of the law schools, having found a source from the internet is not an end in itself. The researcher must still verify the electronic source by examining the actual printed source; once the printed source has been found, there is no point in citing the electronic source over the printed source. This opinion is also supported by Aldrich (2008: 208), that is, when information is available in a traditional print source or on a widely available commercial database, the traditional print source should be cited rather than the internet version. Rumsey (2007-8: 210) mentions that electronic journal articles have coexisted with their paper counterparts in databases like Westlaw and LexisNexis. Legal scholarship, therefore, has long been and may continue to be dominated by citation to print materials (Davis 2006: 641). Margolis (2013: 911) suggests that law without a print-based frame of reference has led to the distinction between legal and non-legal information becoming blurred and is changing people's common understanding of authority.

The results also showed that the majority of web resources that were being cited in the South African electronic legal journals were those that are associated with commercial organisations, that is, the ".com" domain. Perhaps this is because commercial organisations such as database publishers and vendors are also regarded as the authoritative source by the legal researchers. Sherman (2013: 4) provides a distinction between legal and non-legal authority. Citations to cases, statutes and regulations are categorised as legal authorities, whereas non-legal authority is information that is not explicitly "about the law" but information that is nonetheless used as authority in support of legal analysis. In this 
study, it was expected that the large number of domain names or identifiers would be the ones related to Juta daily reports (.jdr) and Judgements online (.jol) domains as primary legal authority sources, as well as those having to do with government organisations (.gov) and non-government organisations (.org); in that they are some of the resources from which primary and secondary sources of legal information can be obtained. This is contrary to the study conducted by Wilkerson (2006) where it was found that government and non-government domains appeared more frequently than the commercial organisation domains in the U.S. Supreme Court opinions. Government departments have much of the legislation that they are administering, including policy documents, speeches, White Papers, Green Papers and other important information for public consumption available on the internet. Non-governmental organisations, such as the Human Rights Organisation, also usually make so much primary information, such as protocols and decisions of the Human Rights organisations available to the public on the internet (Rumsey 2007-8: 201). Surprisingly, the law reports that are regarded as legal authority appear low, after government and non-government organisations domains, and government and non-government organisations appear after the commercial organisation. It is unlikely that most commercial organisations (.com) would contain the primary and secondary sources of information traditionally cited in law review articles (Davis 2006: 641). Perhaps the premise advanced by Davis (2006: 642) namely, that owners of commercial sites have greater incentive or financial means to keep their websites in good working order, holds true or perhaps it is because, as the Royal pingdom blog (2012) states, the ".com" domain name accounts for $74 \%$ of all registered domain names.

There is also the likelihood that legal researchers may not regard such materials from government departments or non-governmental domains as authoritative, because some of them do not look the same as the original sources. The other reason might be that some of the materials from commercial organisations are easily accessible from the internet and may be obtained freely through a Google search, and some through legal information institutes, like SAFLII, which provide legal information such as cases and legislation free of charge to the public. Some legal materials may be accessed through legal search engines such as LawCrawler, Findlaw and Catalaw. Whiteman (2010: 31) noted that today researchers are moving away from law reviews and academic literature to free online sources. To that end, there are several materials that have been published on how to make effective use of the internet for legal research. According to Nevers (2010), Google searching has also become so popular that electronic databases are now being designed to emulate Google.

\section{Conclusion}

This study revealed increasing and later decreasing incidences of web citations in South African electronic law journals form 2005 to 2012. Therefore, despite prevalence of primary and secondary legal information sources on the internet and its platforms, it appears that the usage of information obtained from the internet by legal researchers is decreasing, as demonstrated by low incidences of internet citations in the South African electronic legal periodicals from 2009 to 2012. This should be an issue of concern for those who are involved with impact studies of the internet on scholarly communication in the legal field. Further research on citation patterns, use and user perceptions or preferences with regard to usage of either print or electronic resources among the legal researchers may help to determine the usage behaviour of the internet by legal researchers. According to Davis (2006), legal scholarship has long been and will continue to be dominated by citations to print materials. Further research needs to be conducted with the legal researchers themselves to affirm or refute this assertion. Apart from problems of permanence and authenticity, there is also a question as to whether legal researchers will always use the printed sources because widely-accepted guides to legal citations clearly state that print formats should be used whenever they are available.

The method and materials employed in this study cannot be regarded as absolutely reliable to an extent that final conclusions could be drawn. There are some limitations that can be attributed to the methods and materials applied in this study. Firstly, the fact that the database used in this study does not have an option to search by footnotes made it impossible for the researcher to concentrate on a single search entry when conducting a search. Secondly, the domain names used in this study do not represent all domain names registered and used on the internet. Some of the main internet domain names have been left out, cognisant of the pace at which they are multiplying and the internet is evolving. Further research using different methods and materials to confirm or refute these results could, therefore, still be conducted.

\section{References}

Adriaanse, L.S. \& Rensleigh, C. 2011. Comparing Web of Science, Scopus and Google Scholar from an environmental science perspective. South African journal of libraries and information science, 77 (1): 169-178.

Aguillo, I.F. 2012. Is Google Scholar useful for bibliometrics? A webmetric analysis, Scientometrics, 91(2): 345-351.

Aldrich, K.C. 2008. Web cites: when courts cite URLs: a study of Washington and New York cases, Legal reference services quarterly, 27(2-3): 203-237.

Badertscher, D.G. \& Melnick, D.E. 2010. Is primary legal information on the web trustworthy? The judges' journal, 49(4): 13.

Barratt, A. \& Snyman, P. 2002. Researching South African law. [Online]. http://www.llrx.com/features/southafrica.htm (1 September 2003).

Bekker, L. 1997. Electronic legal research in South Africa. Consultus, May: 69-71.

Bohill, R. 1997. Electronic citation guide for legal materials, Journal of law and information science, 8(2): 210-228. 
Canick, S. 2002. Availability of works cited in recent law review articles on LEXIS, Westlaw, the internet and other databases. Legal references quarterly, 21(2/3): 55-67.

Casserly, M.F. \& Bird J.E. 2003. Web citation availability: analysis and implications for scholarship. College and research libraries, 64(4): 300-317.

Ching, T.S. 2007. The next generation of legal citations: a survey of internet citations in the opinions of the Washington Supreme Court and Washington appellate courts, 1999-2005. Journal of appellate practice and process, 8(2): 387403.

Davis, H.E. 2006. Keeping validity in cite: web resources cited in select Washington law reviews, 2001-03. Law library journal, 98(4): 633-661.

Delgado, R. 1986. How to write a law review article, University of San Francisco law review, 20: 445-454.

Dixon, H.B. 2007. The lack of effort to ensure integrity and trustworthiness of online legal information and documents. The judges' journal, 46: 42-45.

Domain domination: The .com TLD larger than all ccTLD's combined. 2012. Royal pingdom. 20 July. [Online]. Available: http://royal.pingdom.com/2012/07/20/domain-domination-the-com-tld-larger-than-all-cctlds-combined/ (23 September 2013).

Du Plessis, T. 2004. Information and knowledge management in support of legal research in a digital environment. Doctoral thesis. Department of Information Science, Rand Afrikaanse University.

Du Plessis, T. 2008. Competitive legal professionals' use of technology in the legal practice. Potchefstroom electronic law review, 4: 32-60.

Fletcher, G. \& Greenhill, A. 1995. Academic referencing of internet-based resources, Australian library journal, 44 (4): 177-187.

Germain, C.M. 1999. Content and quality of legal information and data on the internet with specific focus on the United States. International journal of legal information, 27(3): 289-306.

Howland, J. \& Wang, C. 2011. Management of legal information in an international context: a conundrum of challenges and opportunities. Frontiers of law in China, 6(2): 165-179.

Liebler, R. \& Liebert, J. 2013. Something rotten in the state of legal citation: the life span of a United State Supreme Court citation containing an internet link (1996-2010). Yale journal of law and technology, 15(2): 273-311.

Manz, W.H. 2001. The citation practices of the New York Court of Appeals: a millennium update. Buffalo law review, 49: $1273-1313$.

Mardani, A. 2012. An investigation of the web citations in Iran's chemistry articles in SCI. Library review, 61(1): 18-29.

Margolis, E. 2013. Authority without borders: the World Wide Web and the delegalization of law. Seton Hall law review, 41:909-912.

Mathews, R.J. \& Baish, M.A. 2007. State by state report on authentication of online legal resources. Washington: American Association of Law Libraries.

Nevers, S.G. 2010. WestlawNext: Westlaw 's next generation research system. Student lawyer, 39(4): 12.

Ngulube, P. \& Thompson E.C.G. 2008. Influence of the World Wide Web on the citation patterns of Master of Information Studies students at the University of Natal during the period 1996 to 2002. South African journal of libraries and information science, 74(2): 160-170.

Obuh, A.O. \& Babatope, I.S. 2011. Students' citation behaviour in Delta State University, Abraka, Nigeria. Library philosophy and practice. Available: http://unllib.unl.edu/LPP/obuh-babatope.htm.

Oermann, M.H., Nordstrom, C. K., Ineson, V., \& Wilmes, N. A. 2008. Web citations in the nursing literature: how accurate are they? Journal of professional nursing, 2(6): 347-351.

Rozenberg, P. 1997. Developing standards for legal citation of electronic information. Murdoch University electronic journal of law, 4(4). Available: http://kirra.austlii.edu.au/aujounals/MurUEJL/1997/35. html (25 October 2010).

Rumsey, M. 2002. Runaway train: problems of permanence, accessibility, and stability in the use of web sources in law review citations. Law library journal, 49(1): 27-39.

Rumsey, M. 2007-8. Gauging the impact of online legal information on international law: two tests. Syracuse journal of law and communication, 35: 201-217.

Sherman, R. 2013. Assessing the changing nature of authority in the web age: the citation practices of Minnesota Supreme Court. MLIS project, University of Washington Information School.

Smyth, R. 2001. Judicial prestige: a citation analysis of federal court judges. Deakin law review, 6(1): 120-147.

Vaughan L. \&Thelwall, M. 2003. Scholarly use of the web: what are the key inducers of links to journal web sites? Journal of the American Society for Information Science and Technology, 54(1): 29-38.

Vreeland, R.C. 2000. Law libraries in hyperspace: a citation analysis of World Wide Web sites. Law library journal, 92(1): 9-25.

Wallace, K. 2012. Top-level domain names. Searcher, 20 (4): 32-34.

Whiteman, M. 2010. The death of the twentieth-century authority. UCLA law review discourse, 58: 27-63.

Widdison, R. 1997. Databases in law firms: an overview. Law technology journal, 3(1). Available: http://www.law.warwick.ac.uk/ Itj/3-1b.html (25 April 2005).

Wilkerson, W.R. 2006. The emergence of internet citations in U.S. Supreme Court opinions. The justice system journal, 27(3):323-338.

Wu, M.C. 2005. Why print and electronic resources are essential to the academic library. Law library journal, 97: 233-248. 
Yang, S., Han, R., Ding, J. \& Song, Y. 2012. Distribution of web citations. Information processing and management, 48(4): 779-790.

Zimmerman, A. 2013. Zimmerman's research guide. [Online]. law.lexisnexis.com/infopro/zimmermans/disp.aspx?z=2085 (04 September 2013). 